\title{
SCIENTIFIC BASIS OF ORGANIZATION OF ECOLOGICALLY SAFE LAND USE
}

\author{
O. Furdychko \\ Doctor of Economics Doctor of Agricultural Sciences, Professor \\ Academician of the NAAS \\ Institute of Agroecology and Environmental Management of NAAS (Kyiv, Ukraine) \\ e-mail: orestfurdychko1010@gmail.com; \\ ORCID: https://orcid.org/0000-0002-1108-7733 \\ O. Drebot \\ Doctor of Economics Sciences, Professor \\ Academician of the NAAS \\ Institute of Agroecology and Environmental Management of NAAS (Kyiv, Ukraine) \\ e-mail:drebot_oksana@ukr.net; \\ ORCID: https://orcid.org/0000-0003-2681-1074 \\ D. Dobryak \\ Doctor of Economics Sciences, Professor \\ Corresponding Member of NAAS \\ Institute of Agroecology and Environmental Management of NAAS (Kyiv, Ukraine) \\ e-mail:d dobryak@ukr.net; \\ ORCID: https://orcid.org/0000-0002-2360-3520 \\ P. Melnyk \\ Doctor of Economics Sciences \\ Senior Research Fellow \\ Institute of Agroecology and Environmental Management of NAAS (Kyiv, Ukraine) \\ e-mail: melnikpp@ukr.net; \\ ORCID: https://orcid.org/0000-0002-6083-677X
}

L. Sakharnatska

$\mathrm{PhD}$ in Economics

Uzhhorod National University (Uzhhorod, Ukraine)

e-mail: ostapchik81@ukr.net;

ORCID: https://orcid.org/0000-0002-5863-4917

The article highlights the environmental problems of land use, its rationalization; optimal use of agricultural lands, in particular, arable lands; a modern interpretation of the content of rational use of agricultural lands. Environmental and economic aspects of this problem are considered. The information data necessary for the decision of this problem are given, namely indicators of natural-agricultural zoning, regional ecological and economic features of manufacture of the basic production of agriculture, indicators of properties and quality of soils and agrobiological requirements of the main crops to natural, primarily soil, environment, indicators of yields of these crops and data on production costs and revenues.

The organization of ecologically safe land use is recommended in three stages. The first stage consists of allocating areas growing certain crops in Ukraine, that agroecological interpretation materials natural and agricultural zoning to study the environmental conditions of production agriculture. If the growing zones of certain crops have specific, inherent only in each of them, geographical areas, then it is determined where and which crops in terms of natural conditions should be located.

The second stage of identifying the ecological and economic features of the production of basic agricultural products based on data on natural conditions, especially soil, is to determine the suitability of land for the area within the growing zones.

The third stage of the organization of ecologically safe land use is to determine according to the data on the suitability of soils of the territory with optimal conditions for growing the crop, i.e. where the best and with the highest assessment of soils prevail. The growing zone can have at least three such agronomic regions (districts) - with the best, average, and worst conditions. In modern conditions, when prices of goods forming market relations, accounting for differences in land productivity as a productive resource becomes a necessary objective condition for the profitable and ecologically safe existence of agriculture.

Keywords: suitability, profitability, ecologically safe land use, growing zones, agricultural crops. 


\section{INTRODUCTION}

In modern conditions of maturing ecological crisis ecologically safe use of agricultural lands should be considered as the primary basis of development of society as a whole. Such use may be when agricultural production operates in full concordance with environmental safety laws.

Agricultural lands make up $69.3 \%$ of the entire territory of Ukraine, arable land in their composition - $75.5 \%$. These data confirm the importance of the rational use of agricultural land, particularly arable land.

With the development of society, humanity is enriched with knowledge about the earth and the environment. With the accumulation of relevant information, as well as depending on the attitude of society to agriculture, the ways of using the earth's surface to obtain the necessary crop products are transformed.

Even now, the content of the rational use of agricultural land is interpreted mostly ambiguously. Most of all, it corresponds to the essence of the concept, which contains, first of all, ecological and economic features of farming production. In this case, the rational use of agricultural land, especially arable land, can be considered as one in which a scientifically sound economic effect of society is achieved and the improvement of the environment and land as one of its main components. This should adhere to the condition: arable land should be used by the capabilities of the natural potential of soils, taking into account the needs of protection and increase their fertility.

From the point of view of the formulated understanding of rational land use it is necessary to consider ecological and economic aspects of this problem. Certain that it can be solved by modeling the future ecologically balanced natural environment, ie the ecosphere, and the economic security that is needed to achieve ecological balance and the main goal: produce agricultural products, necessary for society in terms of range, quality, and quantity.

In this case, first of all, solve a set of questions to improve the location of agricultural about the natural features of the regions of Ukraine and the organization of ecologically safe use of agricultural lands, and also develop and implement a mechanism of economic incentives for ecologically safe land use. Rational use in this sense can be ensured only when the organization of land use will be based on information about the characteristics of the relationships, formed in the evolution of development between crops and the natural environment, mainly soil, and constitute a closed system of mutual preservation and enrichment. Measures to protect and increase land fertility at the same time must be an integral part of the technology of growing crops.

Such information includes all data, indicators and data of the land cadastre and materials that accompany the development of its components, including the establishment of the suitability of arable land for the production of agricultural products. From these materials regional ecological and economic features of production of the main agricultural products of Ukraine characterize: natural and agricultural zoning, indicators of the properties and quality of soil and agrobiological requirements of major crops to natural primarily soil, environment, indicators of yields of these crops and data on production costs and revenues.

The research aims to substantiate the scientific foundations of the organization of ecologically safe land use, identify unresolved issues and propose approaches to address them.

\section{ANALYSIS OF THE LASTS RESEARCH AND PUBLICATIONS}

Problems of organization of ecologically safe land use devoted to the work and research of such domestic scientists as D. Babmindra, A. Boiko, S. Bulyhin, D. Dobriak, O. Drebot, T. Yevsiukov, O. Kanash, A. Martyn, P. Melnyk, I. Novakovska, O. Furdychko, and others [1-8].

Despite the significant achievements of leading scientists, economists, soil scientists, it should be noted the lack of comprehensive research on this problem, especially in market conditions - namely, the need for further research on the organization of ecologically safe land use.

To allocation of previously unsolved parts of the overall problem. Analysis of recent research and publications on the organization of ecologically safe land use shows deficits in the institutional provision, formation, and development of ecologically safe land use, especially at the regionals level.

\section{MATERIALS AND METHODS RESEARCH}

Based on the analysis of the essence and data natural-agricultural zoning, bonitetnoyi, and normative-monetary assessment of agricultural lands, developed land management projects of agricultural enterprises allocated the negative aspects of agricultural land, their degradation, and the causes of these processes.

\section{RESULTS AND DISCUSSION}

The ecological and economic situation in the country indicates the inconsistency and imbalance of environmental and economic issues in 
land use, which negatively affects the environment. Imbalance of the structure of sown areas, neglect of crop rotations, giving priority to row soil-depleting crops, export-oriented agricultural products (sunflower, rapeseed, corn for grain, etc.), sown areas which annually increase many times with a decrease in forage crops by more, as a result, the condition of the soil cover deteriorates due to the increase of degraded lands, the dynamics of reduction of humus content in soils is traced, as the main energy resource that ensures their productivity (table 1).

Table 1

Dynamics of humus content in the soils of arable lands of Ukraine

\begin{tabular}{|c|c|c|c|c|c|c|c|c|c|}
\hline \multirow[b]{2}{*}{$\underset{\mathbf{N} \backslash \mathbf{o}}{\mathbf{n} \backslash \mathbf{n}}$} & \multirow[b]{2}{*}{ Administrative entities } & \multicolumn{4}{|c|}{ Humus content, $\%$} & \multicolumn{2}{|c|}{$\begin{array}{c}\text { Decrease in humus } \\
\text { content for 1961- } \\
2015\end{array}$} & \multicolumn{2}{|c|}{$\begin{array}{l}\text { Decrease in } \\
\text { humus content } \\
\text { for } 1882-1981\end{array}$} \\
\hline & & 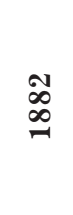 & $\ddot{\mathscr{\sigma}}$ & $\begin{array}{l}\vec{\infty} \\
\stackrel{\sigma}{g}\end{array}$ & $\stackrel{10}{\stackrel{2}{~}}$ & $\begin{array}{l}\frac{0}{0} \\
\frac{0}{5} \\
0 \\
0 \\
\frac{0}{\sigma}\end{array}$ & 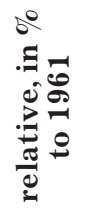 & $\begin{array}{l}\frac{0}{0} \\
\frac{0}{5} \\
\frac{0}{0} \\
0 \\
\frac{0}{\sigma}\end{array}$ & 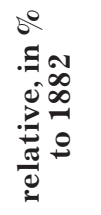 \\
\hline 1. & Crimea & 3,0 & 2,8 & 2,4 & 2,3 & 0,5 & 17,8 & 0,6 & 20,0 \\
\hline 2. & Vinnytsia & 3,5 & 3,1 & 2,9 & 2,8 & 0,3 & 9,7 & 0,6 & 17,1 \\
\hline 3. & Volyn & 2,0 & 1,8 & 1,6 & 1,6 & 0,2 & 11,0 & 0,4 & 20,0 \\
\hline 4. & Dnepropetrovsk & 5,5 & 4,3 & 4,5 & 4,4 & 0,5 & 10,2 & 1,0 & 18,1 \\
\hline 5. & Donetsk & 5,0 & 4,6 & 4,3 & 4,2 & 0,4 & 8,7 & 0,7 & 14,0 \\
\hline 6. & Zhytomyr & 2,6 & 2,3 & 1,9 & 1,9 & 0,4 & 17,4 & 0,7 & 26,9 \\
\hline 7. & Zakarpattya & - & 3,1 & 2,3 & 2,6 & 0,5 & 16,1 & - & - \\
\hline 8. & Zaporozhye & 4,0 & 3,4 & 3,1 & 3,0 & 0,4 & 11,8 & 0,9 & 22,5 \\
\hline 9. & Ivano-Frankivsk & - & 2,8 & 2,5 & 2,5 & 0,4 & 13,8 & - & - \\
\hline 10. & Kyiv & 4,0 & 3,3 & 3,1 & 2,8 & 0,5 & 15,2 & 0,9 & 22,5 \\
\hline 11. & Kirovograd & 5,5 & 4,8 & 4,5 & 4,3 & 0,5 & 10,4 & 1,0 & 18,1 \\
\hline 12. & Luhansk & 5,5 & 4,7 & 4,4 & 4,2 & 0,5 & 10,6 & 1,1 & 20,5 \\
\hline 13. & Lviv & - & 2,5 & 2,1 & 2,0 & 0,5 & 20,0 & - & - \\
\hline 14. & Mykolayivska & 4,5 & 4,1 & 3,8 & 3,3 & 0,8 & 19,5 & 0,7 & 15,5 \\
\hline 15. & Odessa & 4,2 & 3,7 & 3,3 & 3,2 & 0,5 & 13,5 & 0,9 & 21,4 \\
\hline 16. & Poltava & 5,0 & 4,3 & 4,0 & 3,9 & 0,4 & 9,3 & 1,0 & 20,0 \\
\hline 17. & Rivne & - & 2,3 & 1,9 & 1,9 & 0,4 & 17,4 & - & - \\
\hline 18. & Sumy & 4,5 & 4,0 & 3,7 & 3,6 & 0,4 & 10,0 & 0,8 & 17,7 \\
\hline 19. & Ternopil & 3,6 & 3,3 & 3,0 & 2,9 & 0,4 & 12,1 & 0,6 & 16,6 \\
\hline 20. & Kharkiv & 7,0 & 5,3 & 4,9 & 4,6 & 0,7 & 13,2 & 1,1 & 15,7 \\
\hline 21. & Kherson & 3,0 & 2,6 & 2,3 & 2,2 & 0,4 & 15,3 & 0,7 & 23,3 \\
\hline 22. & Khmelnytsky & 3,5 & 3,1 & 2,8 & 2,7 & 0,4 & 12,9 & 0,7 & 19,9 \\
\hline 23. & Cherkasy & 4,0 & 3,5 & 3,2 & 3,1 & 0,4 & 11,4 & 0,8 & 20,0 \\
\hline 24. & Chernivtsi & 4,0 & 3,4 & 3,0 & 2,9 & 0,5 & 14,7 & 1,0 & 25,0 \\
\hline 25. & Chernihiv & 2,5 & 2,2 & 2,0 & 1,9 & 0,3 & 13,6 & 0,5 & 20,0 \\
\hline \multicolumn{2}{|c|}{ Total in Ukraine } & - & 3,5 & 3,2 & 3,1 & 0,4 & 11,4 & - & - \\
\hline
\end{tabular}

Source: *calculated based on materials of the Institute of Land Management, the Institute of Soil Science and Agrochemistry named after ON Sokolovsky and NSC «Soil Fertility» 
Therefore, the organization of ecologically safe land use in such conditions should be carried out based on complex information, which is contained in the data of natural-agricultural zoning, which, as indicated by Academician O.I. Furdychko are identical «(agroecological zoning) and the basis for the rational use of land» [9; 11, p. 268].

Natural and agricultural zoning of the territory of Ukraine is divided into zones, mountainous areas; zone (region) - in the province; province - the natural and agricultural areas. District - is the smallest part of the territory, which is homogeneous in terms of climate, geomorphology, physical and geographical features, soil cover, and other factors that significantly affect the plant world and form a certain ecological niche. Characteristics of the climate of areas make it possible to determine the area within which the cultivation of a particular crop will have optimal (in certain ranges) agroclimatic conditions. This territory is a zone of growing crops.

Given the current practice of using agricultural land, considering previous times, scientifically substantiated systems of agriculture and, first of all, crop rotation is violated on a large scale in the state, which leads to significant amounts of soil degradation.

The allocation of growing zones of certain crops on the territory of Ukraine is the first stage of the agroecological interpretation of materials of natural agricultural zoning to study the ecological conditions of agricultural production.

When we take into account that the growing zones of certain crops have specific, unique to each of them, geographical areas, it emerges where and what crops in terms of natural conditions should be located.

The second stage of selection of ecological and economic features of production of the basic products of agriculture based on data on natural conditions, first of all, soil, consists in the definition of suitability land for crops of each naturalagricultural area within the growing zones.

According to the data on the suitability of soils, the third stage of the agroecological study of the earth's surface is carried out, as a result of which an area with optimal ecological conditions for growing crops is found, ie where the best and higher estimate soils predominate. Growing zone, in this case, may have at least three such regions, agroecological districts with the best, medium, and worst conditions.

Based on the performance of the area in varying degrees of arable land suitable and yield points determine the potential production volumes in the best environmental conditions.
The calculations are carried out according to the formula:

$$
V P p m j=(P l p j \times K \times P r n j) \times(U s j B j / B s j),(1)
$$

where: VPpmj - potentially possible volume of production of the $\mathrm{j}$ - th culture, Plpj - the area of the soils suitable for $\mathrm{j}$ - th culture (for grain crops is the best, average and limited suitability of arable lands, for corn and other row crops, and also flax - only the best and average suitability), Prnj - the percentage of sowing of the $\mathrm{j}$ - the crop in crop rotation (plodozmini), Bsj and $\mathrm{Bj}$ - respectively, the average score of arable land and the suitable area for the $\mathrm{j}$ - the crop, Usj - average for the last 5-7 years productivity of $\mathrm{j}$ - the culture, or cadastral productivity, $\mathrm{K}$ - coefficient of bringing of the suitable area to crop rotations.

Comparing the potential volume of products in the areas of cultivation of one or another agricultural crop with national needs in it, there may be several options: 1) the calculated volumes meet the national needs for products and its production is concentrated in better environmental conditions with lower than in Ukraine as a whole, the cost, because, as a rule, in better conditions, production costs are much lower than with medium and worse; 2 ) identified volumes outweigh the need; 3 ) the calculated volumes do not meet national needs.

In this case, considering: a) the possibility of introducing crop rotation with a higher concentration of crops; b) expansion of crops in less suitable areas, which means obtaining more expensive products by financing measures to protect soils and increase their fertility and provide for the selection of varieties adapted to the worst environmental conditions; c) the import of insufficient volumes of specific products, provided that the purchase price is lower than the additional losses in the production of these products on the worst lands.

Depending on the available option, the directions of state ecological, resource, and legal regulation of ecologically safe use of lands in agriculture should be formed and implemented. These include guaranteed purchase by the state of certain volumes of agricultural products at prices that ensure parity of cost accounting between agricultural and industrial producers; targeted supply to the agriculture of resources necessary for the production of products for the purpose of state-guaranteed procurement; introduction of standards that ensure environmentally safe use of agricultural land and production of products of the required quality.

The first two areas determine the rational use of agricultural land at the regional level, the 
third can be carried out directly by producers using specific land plots.

In modern conditions, when commodity prices are formed by market relations, taking into account differences in the productivity of land as a productive resource becomes a necessary objective condition for the profitable existence of agriculture.

The deepening of regional specialization of agriculture is connected with prospects of development of animal husbandry and processing enterprises, placement of the industrial centers, and transport communications, with the decision of problems of more improved use of land resources. It brings together a wide range of issues. Distribution of land between sectors of the economy, preservation of fertile land for agricultural production and careful and economical treatment of them, forecast of the most efficient location, specialization and organization branches of agriculture, land management and organization of land taking into account differences in soil quality - all this applies to the rational use of land.

It is important to emphasize the connection between the study of land resources and the forecast of their use with the definition of the development of agricultural production by region and in some agricultural enterprises. First of all, it should be taken into account that all the obtained information on the natural environment is the source and generalized at the level of units of natural-agricultural zoning and individual agricultural enterprises, including cartographic, most detailed characterizes the current state of the territory of any area in natural and economic terms. When comparing it with the actual use, it is possible to determine how economically and efficiently land resources are exploited, whether the composition of lands corresponds to agrotechnical and reclamation measures to preserve and improve soil quality, whether the placement of the main crops in crop rotation is ensured by the areas suitable for them. From this, we can conclude how favorable soil conditions are for the existing specialization of industries and, most importantly, for the specialization of agriculture, and what should be its direction in the future, provided a steady increase in soil fertility.

The above condition can be achieved if the composition and location of land, crop rotation arrays, and fields in rotation, as the structure of crops, are designed by the data on the suitability of soils. They also take into account the fact that the structure and location of crops are also regulated by the general conditions of proper crop rotation.
Information on the suitability of soils for growing crops characterizes the ability of agricultural enterprises to produce certain types of agricultural products. The most important and responsible moment, namely the organization of ecologically oriented use of land plots, is carried out based on a map of the suitability of soils for growing crops. It is the main source document for ecologically safe land use, which synthesizes soil quality indicators by the agrobiological requirements of crops, as well as concentrates current data on the boundaries and areas of agricultural lands, individual areas of soils, and subclasses of their suitability.

The synthesized information is recorded on maps; in generalized form, they serve as a source of information for deepening regional specialization and improving the location of agricultural sectors, and thus land use is closer to the differentiated productivity of the ecological environment.

Based on these data, we can calculate the economic efficiency of concentrating the production of the bulk of the required agricultural products in the relevant biological properties of each agricultural crop in ecological conditions. Society is directly interested in locating the production of the main types of plant (agricultural) products in the best agroecological conditions. Such concentration should be regulated by the state-guaranteed purchase of a certain volume of products from specific producers at parity prices due to the law of value, as well as administrative levers, based on the relevant law of Ukraine.

The difference in average existing purchase prices is the first component of the efficiency of ecologically oriented land use. The second is the difference in the cost of production. Both the first and the second component should be positive, as the cultivation of crops in the optimal ecological environment is cheaper, with lower costs compared to the average conditions which exist and depend on the actual state location of production at the moment.

Undoubtedly, the long-term and promising should be considered ecological effect, which is manifested in the politeti of specific land plots and individual fields, as well as large areas due to the positive interaction of vegetation with the soil environment. Such interaction is conditioned by the coordination of agrobiological requirements of crops to climatic conditions, soil quality and increase of crop productivity, enrichment of soils with significant plant mass. Thus, the primary and most important lever for the rational use of productive agricultural land is the state economic incentives in combination with ecologically oriented placement of crop produc- 
tion (agriculture), as well as based on the relevant law.

Ecologically safe land use should also be regulated by purely economic methods through differentiated taxation and land price formation, and land tax rates are set on the basis of the cadastral value of income. Two aspects deserve attention.

The first aspect is that one of the main purposes of the land tax is to provide for the stimulate income from the use of all land, that is, even the worst land quality soils and locations could be used efficiently, and this would generate income that would offset and exceed the tax. Given the dynamics of prices, there is a need to regulate land taxation so that land tax does not lose its role as an economic lever to improve land-use efficiency and remains objective, adequately responding to changes in prices for agricultural and industrial products. Previously, it was practiced to increase the initial rate of land tax by the index of growth of prices for agricultural products. This method does not correlate with the principles of determining rates for agricultural land, adopted in the Law of Ukraine «On Payment for Land». Studies show that adequacy can be met if land tax rates increase according to the income growth index due caused by price dynamics. The latter is derived from the index of rising prices for agricultural and industrial products and changes in the standards of profitability of agricultural production.

The introduction of a fiscal tax on agricultural land use launched and positive results of the event can be set not less than 5 years.

The second aspect of purely economic regulation of ecologically safe land use is that the initial, in terms of sale at auction, the price of land to be defined as promising. To do this, income should be determined on the basis of potentially possible production volumes and income, based on soil suitability and agrobiological justification of crop rotation.

\section{CONCLUSIONS}

Given the above, it can be stated that:

1) data on the suitability of soils and land valuation materials in general are the basis for finding for ecologically oriented land use;

2 ) the application of the whole set of land valuation data and ecological characteristics brings together the use of land with diverse differentiation of soil quality and location of land plots (fields, land plots, agricultural enterprises, regions);

3) ecologically safe land use provides progressive positive, ecological, and economic efficiency, and, most importantly, the growth of economic efficiency, which can guarantee the existence of balanced ecosystems as components of the ecosphere.

\section{REFERENCES}

1. Babmindra, D.I. (2002). Kryzovi yavyshcha u silskohospodarskomu zemlekorystuvanni (teoriia, metodolohiia, praktyka) [Crisis phenomena in agricultural land use (theory, methodology, practice)]. Problems of development of land relations on the basis of the new Land Code of Ukraine: Proceedings of the AllUkrainian Conference (pp. 121-125). Kyiv: Instytut zemleustroiu UAAN [in Ukrainian].

2. Boiko, A.L. (1990). Ekolohiia roslynnykh virusiv [Ecology of plant viruses]. Kiev: Vysshaya shkola [in Russian].

3. Bulyhin, S.Iu. (2005). Formuvannia ekolohichno stiikykh ahrolandshaftiv [Formation of ecologically sustainable agrolandscapes]. Kyiv: Urozhai [in Ukrainian].

4. Dobriak D.S., Kanash O.P., Babmindra D.I., \& Rozumnyi I.A. (2009). Klasyfikatsiia silskohospodarskykh uhid yak naukova peredumova yikh ekolohichnoho vykorystannia [Classification of agricultural lands as a scientific prerequisite for their environmentally friendly use]. Kyiv: Urozhai [in Ukrainian].

5. Dobriak, D.S. (2016). Naukovo-metodychni pohliady na intensyfikatsiiu zemlekorystuvannia silskohospodarskykh pidpryiemstv [Scientific and methodological views on the intensification of land use of agricultural enterprises]. Visnyk KhNAU. Seriia: Ekonomichni nauky, 1, 64-70 [in Ukrainian].

6. Dobriak, D.S., Martyn, A.H., \& Yevsiukov, T.O. (2010). Upravlinnia zemleiu ta adaptatsiia do yevropeiskykh vymoh [Land management and adaptation to European requirements]. Land management and cadastre. 3, 3-9 [in Ukrainian].

7. Drebot, O.I., Vysochanska, M.Ya. (2016). Kontseptualni pryntsypy zbalansovanoho vykorystannia zemelnykh resursiv u silskomu hospodarstvi [Conceptual principles of balanced use of land resources in agriculture]. Zbalansovane pryrodokorystuvannia - Balanced nature management, 4, 131-137 [in Ukrainian].

8. Drebot O., Shershun M., Sakharnatska L. and Vysochanska M. (2019). Napriamky orhanizatsiino-investytsiinoho mekhanizmu vykorystannia silskohospodarskykh landshaftiv [Directions of the organizational and investment mechanism of agricultural landscapes use]. Scientific Papers Series Management, Economic Engineering in Agriculture and Rural Development, 19, 3, 125-133 [in Romania]. 
9. Melnyk, P. P. (2016). Ekoloho-ekonomichni osnovy pryrodokorystuvannia v ahroekosystemakh [Ecological and economic bases of nature management in agroecosystems]. Kyiv: DAI [in Ukrainian].

10. Novakovska, I. O. (2013). Osnovy ekonomiky zemlekorystuvannia: monohrafiia [Fundamentals of land use economics: monograph]. Kyiv: Prosvita [in Ukrainian].

11. Furdychko, O. I. (2014). Ekolohichni osnovy zbalansovanoho rozvytku ahrosfery v konteksti yevropeiskoi intehratsii Ukrainy: monohrafiia [Ecological bases of balanced development of agrosphere in the context of European integration of Ukraine: monograph]. Kyiv: DIA [in Ukrainian].

\title{
НАУКОВІ ОСНОВИ ОРГАНІЗАЦІЇ ЕКОЛОГОБЕЗПЕЧНОГО ЗЕМЛЕКОРИСТУВАННЯ
}

\author{
O.I. Фурдичко \\ доктор економічних наук, доктор сільськогосподарських наук, \\ профресор, академік НАAН \\ Інститут агроекології і природокористування НААН (м. Київ, Україна) \\ e-mail: orestfurdychko1010@gmail.com; \\ ORCID: https://orcid.org/0000-0002-1108-7733 \\ O.I. Дребот \\ доктор економічних наук, професор, \\ академік НАAН \\ Інститут агроекології і природокористування НАAН (м. Київ, Україна) \\ e-mail: drebot_oksana@ukr.net; \\ ORCID: https: / /orcid.org/0000-0003-2681-1074 \\ Д.С. Добряк \\ доктор економічних наук, професор, \\ член-кореспондент НАAН, \\ Заслужений діяч науки і техніки України \\ Інститут агроекології і природокористування НАAН (м. Київ, Україна) \\ e-mail: d_dobryak@ukr.net; \\ ORCID: https://orcid.org/0000-0002-2360-3520 \\ П.П. Мельник \\ доктор економічних наук, \\ старший науковий співробітник \\ Інститут агроекології і природокористування НАAН (м. Київ, Україна) \\ e-mail: melnikpp@ukr.net; \\ ORCID: https://orcid.org/0000-0002-6083-677X \\ Л.I. Сахарнацька \\ кандидат економічних наук, доцент \\ ДВНЗ «Ужгородський національний університет» \\ e-mail: ostapchik81@ukr.net; \\ ORCID: https: / /orcid.org/0000-0002-5863-4917
}

У статті висвітлено екологічні проблеми землекористування, його раціоналізації; оптимальне використання сільсъкогосподарсъких угідъ, зокрема орних земель; сучасна трактовка змісту раціоналъного використання сільсъкогосподарсъких земель. Розглядаються екологічні та економічні аспекти изъого питання. Наводятъся інбормаційні дані, які необхідні для вирішення изєї проблеми, а саме показники природно-сільсъкогосподарсъкого районування, регіоналъні еколого-економічні особливості виробництва основної продукції землеробства, показники властивості та якості грунтів і агробіологічні вилоги основних сілъсъкогосподарсъких кулътур до природного, насамперед грунтового середовища, показники про врожайність ијих культур та дані про виробничі витрати $i$ доходи.

Організачію екологобезпечного землекористування рекомендується здійснювати в три етапи. Перший етап полягає у виділенні зон вирошування окремих культур на території України, тобто агроекологічної інтерпретації матеріалів природно-сілъсъкогосподарсъкого районування з метою вивчення екологічних умов виробництва продукиї землеробства. Якщо зони вирощування певних культур мають конкретні, притаманні тільки кожній із них, географбічні ареали, тоді визначаєтъся, де і які сілъсъкогосподарсъкі кулътур із погляду природних умов необхідно розміщувати.

Другий етап виявлення еколого-економічних особливостей виробництва основних продуктів землеробства на базі даних про природні умови, передусім грунтові, полягає у визначенні придатності земельних ділянок для району в межах зон вирошування. 
Третій етап організачї екологобезпечного землекористування полягає у визначенні за даними про придатність грунтів територї з оптилальними умовали для вирошування культури, тобто де переважають краші й з вищою очінкою для неї грунти. Зона вирошування в такому може мати як мінімум три таких агрономічні регіони (округи) - з кращими, середніми і гіриими умовами.

У сучасних умовах, коли иіни на товари бормуютвся ринковими відносинами, облік відмінностей продуктивності землі як виробничого ресурсу стає необхідною об'єктивною умовою прибуткового і екологобезпечного існування сільсъкого господарства.

Ключові слова: придатність, прибутковість, екологобезпечне землекористування, зони вирошування, сілъсъкогосподарсъкі кулътури.

\section{ЛITEPATУРА}

1. Бабміндра Д.І. Кризові явища у сільськогосподарському землекористуванні (теорія, методологія, практика). Проблеми розвитку земельних відносин на засадах нового Земельного кодексу України: матеріали Всеукр. наук. конф. Київ: Інститут землеустрою УААН, 2002. С. 124-125.

2. Бойко А.Л. Экология вирусов растений. Киев: Высшая школа, 1990, 167 с.

3. Булигін С.Ю. Формування екологічно сталих агроландшафтів. Київ: Урожай, 2005,300 с.

4. Добряк Д.С., Канаш О.П., Бабміндра Д.І., Розумний І.А. Класифікація сільськогосподарських земель як наукова передумова їх екологобезпечного використання: 2-ге вид., доп. Київ: Урожай, 2009. 464 с.

5. Добряк Д.С. Науково-методичні погляди на інтенсифікацію використання земельних ресурсів сільськогосподарських підприємств. Вісник ХНАУ. Серія: Економічні науки. 2016. № 1. С. 64-70.

6. Добряк Д.С., Мартин А.Г., Свсюков Т.О. Управління земельними ресурсами і адаптація до європейських вимог. Землеустрій і кадастр. 2010. № 3. С. 3-9.

7. Дребот О.І., Височанська М.Я. Концептуальні засади збалансованого використання земельних ресурсів у сільському господарстві. Збалансоване природокористування. 2016. № 4. С. 131-137.

8. Мельник П.П. Еколого-економічні основи управління природокористуванням в агроекосистемах. Київ: ДІА, 2016. 328 с.

9. Новаковська І.О. Основи економіки землекористування: монографрія. Київ: Просвіта, 2013.224 с.

10. Фурдичко О.І. Екологічні основи збалансованого розвитку агросфери в контексті європейської інтеграції України: монографія. Київ: ДІА, 2014. 430 с.

\section{ВІДОМОСТІ ПРО АВТОРІВ}

Фурдичко Орест Іванович, доктор економічних наук, доктор сільськогосподарських наук, професор, академік НАAН, головний науковий співробітник, Інститут агроекології і природокористування НААН (вул. Метрологічна, 12, м. Київ, 03143, Україна; e-mail: orestfurdychko1010@gmail. com; ORCID: https://orcid. org/0000-0002-1108-7733)

Дребот Оксана Іванівна, доктор економічних наук, професор, академік НАAН, заслужений діяч науки і техніки України, Інститут агроекології і природокористування НААН (вул. Метрологічна, 12, м. Київ, 03143, Україна; e-mail: drebot_oksana@ukr.net; ORCID: https://orcid.org/0000-00032681-1074)

Добряк Дмитро Семенович, доктор економічних наук, професор, член-кореспондент НААН, заслужений діяч науки і техніки України, головний науковий співробітник, Інститут агроекології і природокористування НАAН (вул. Метрологічна, 12, м. Київ, 03143, Україна; e-mail: d_dobryak@ ukr.net; ORCID: https://orcid.org/0000-0002-2360-3520)

Мельник Петро Павлович, доктор економічних наук, старший науковий співробітник, заступник завідувача відділу інституціонального забезпечення природокористування, Інститут агроекології і природокористування НААН (вул. Метрологічна, 12, м. Київ, 03143, Україна; е-mail: melnikpp@ukr.net; ORCID: https://orcid.org/0000-0002-6083-677X);

Сахарнацька Людмила Іванівна, кандидат економічних наук, доцент ДВНЗ «Ужгородський національний університет» (пл. Народна, 3, м. Ужгород, 88000, Україна; e-mail: ostapchik81@ukr. net; ORCID: https://orcid.org/0000-0002-5863-4917) 